\title{
Fluorometric recognition of both dihydrogen phos- phate and iodide by a new flexible anthracene linked benzimidazolium-based receptor
}

\author{
Kumaresh Ghosh ${ }^{*}$ and Debasis Kar
}

Open Access

\author{
Full Research Paper \\ Address: \\ Department of Chemistry, University of Kalyani, Kalyani-741235, India \\ Email: \\ Kumaresh Ghosh ${ }^{*}$ - ghosh_k2003@yahoo.co.in \\ * Corresponding author \\ $\S$ Fax: +913325828282; Tel: +913325828750 \\ Keywords: \\ anthracene coupled receptor; benzimidazolium-based receptor; \\ dihydrogenphosphate recognition; iodide recognition
}

\author{
Beilstein J. Org. Chem. 2011, 7, 254-264. \\ doi:10.3762/bjoc.7.34 \\ Received: 26 August 2010 \\ Accepted: 26 January 2011 \\ Published: 25 February 2011 \\ Associate Editor: P. J. Skabara \\ () 2011 Ghosh and Kar; licensee Beilstein-Institut. \\ License and terms: see end of document.
}

\begin{abstract}
A new flexible anthracene linked benzimidazolium-based receptor $\mathbf{1}$ has been designed, synthesized and its binding properties have been studied by NMR, UV-vis and fluorescence spectroscopic techniques. While the receptor $\mathbf{1}$ exhibits a greater change in emission in the presence of tetrabutylammonium dihydrogenphosphate in $\mathrm{CH}_{3} \mathrm{CN}$ over the other anions studied, iodide is selectively preferred in $\mathrm{CHCl}_{3}$ containing $0.1 \% \mathrm{CH}_{3} \mathrm{CN}$. Upon complexation of dihydrogen phosphate and iodide, the emission of $\mathbf{1}$ gradually decreased without showing any other characteristic change in the spectra. Hydrogen bonding and charge-charge interactions interplay simultaneously in a cooperative manner for selectivity in the binding process.
\end{abstract}

\section{Introduction}

The selective recognition of anionic species by artificial abiotic receptors is a rapidly growing area in supramolecular chemistry [1-6]. Anion recognition has gained significant importance as it plays an important role in a wide range of biological, environmental and chemical processes [7-10]. Sensors based on anioninduced changes in fluorescence appear to be particularly attractive in anion recognition due to the simplicity and high detection limit of fluorescence $[11,12]$. In devising such sensors, various functional sites with hydrogen bond donors and acceptors are of considerable importance. Among the different binding motifs for anions, the hydrogen bonding properties of
NH groups in neutral amines [13], amides [14], ureas/thioureas $[15,16]$, indoles [17-19] and pyrroles [20] as well as in guanidinium [21] and imidazolium [22] groups are well established. In addition, the use of the benzimidazolium motif [23,24] in anion recognition is also known. During the course of our work on anion recognition, we used this motif along with the other functionalities for selective recognition of carboxylates, and dihydrogen phosphate [25]. Selective recognition of dihydrogen phosphate is an important aspect of supramolecular chemistry and various receptors of different designs for this anion have been reported in the literature [26-33]. 

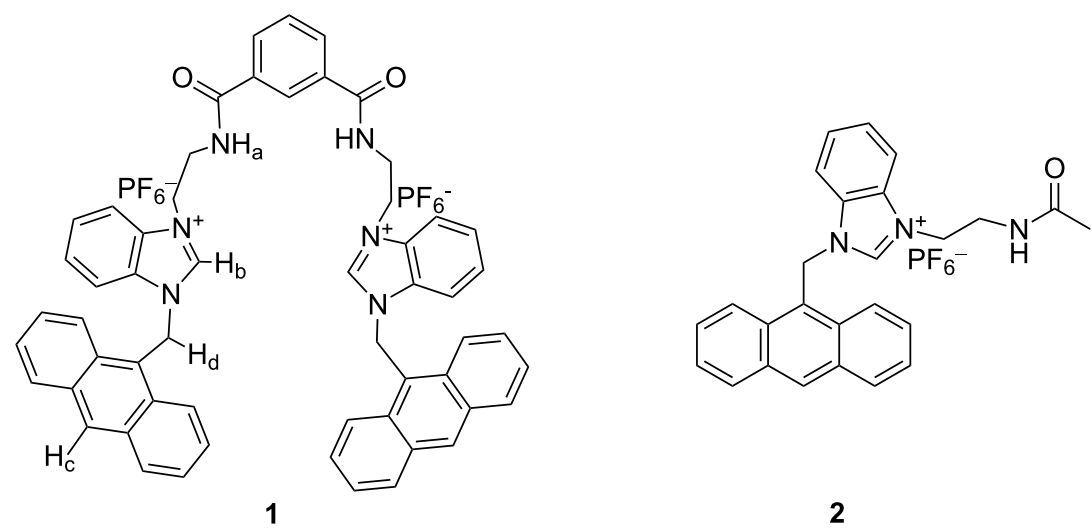

Figure 1: Synthesized compounds 1 and 2.

In an effort to investigate the anion recognition behavior of the benzimidazolium group in the presence of a flexible spacer, we report herein the design and synthesis of a new chemosensor $\mathbf{1}$ (Figure 1), which shows selective recognition of dihydrogen phosphate in $\mathrm{CH}_{3} \mathrm{CN}$ among the other anions studied. The selectivity is changed on changing the polarity of the solvent, and the receptor 1 exhibits a preference for iodide when $\mathrm{CH}_{3} \mathrm{CN}$ is replaced by $\mathrm{CHCl}_{3}$ containing $0.1 \% \mathrm{CH}_{3} \mathrm{CN}$. The results were compared with the monomeric unit 2 (Figure 1).

\section{Results and Discussion}

The receptor 1 was obtained according to Scheme 1. Initially, 2-chloroethylamine was reacted with isophthaloyl dichloride to afford the diamide $\mathbf{4}$ in $80 \%$ yield. Subsequent reaction of $\mathbf{4}$ with anthracene coupled benzimidazole 3 (prepared in 64\% yield from benzimidazole and 9-chloromethylanthracene in the presence of $\mathrm{NaH}$ in dry THF) gave the dichloride salt 5 in 55\% yield. Anion exchange using $\mathrm{NH}_{4} \mathrm{PF}_{6}$ in warm aqueous $\mathrm{CH}_{3} \mathrm{OH}$ gave the desired compound $\mathbf{1}$ in $90 \%$ yield. Similarly, model a)

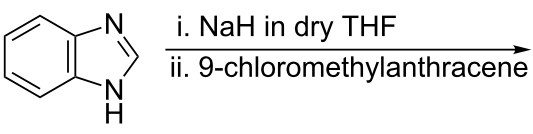<smiles></smiles>

i. 3, dry $\mathrm{CH}_{3} \mathrm{CN}$, reflux ii. $\mathrm{NH}_{4} \mathrm{PF}_{6}$, aq $\mathrm{CH}_{3} \mathrm{OH}$<smiles>O=C(NCCCl)c1cccc(C(=O)NCCCl)c1</smiles>
3, dry $\mathrm{CH}_{3} \mathrm{CN}$, reflux<smiles></smiles> 
compound 2 was obtained in $64 \%$ yield from the reaction between 6 and 3 in dry $\mathrm{CH}_{3} \mathrm{CN}$ followed by anion exchange using $\mathrm{NH}_{4} \mathrm{PF}_{6}$ in aqueous $\mathrm{CH}_{3} \mathrm{OH}$. All the compounds were characterized unequivocally by ${ }^{1} \mathrm{H} \mathrm{NMR},{ }^{13} \mathrm{C}$, mass spectrometry and FTIR.

In receptor $\mathbf{1}$, two amide NHs and two benzimidazolium protons $\left(\mathrm{C}^{+}-\mathrm{H}\right)$ are accessible for the complexation of anions. The residual charge on each benzimidazolium motif, in principle, will stabilize the complex by charge-charge interaction. It is quite rational that the binding group in each arm of flexible receptor 1 could either be involved cooperatively or functions individually for complexation of anions. Thus the selectivity in the binding process is related with the disposition of the binding groups around the isophthaloyl spacer. Figure 2, for example, shows the energy-optimized geometry of the complex of $\mathbf{1}$ with $\mathrm{H}_{2} \mathrm{PO}_{4}{ }^{-}$in the gas phase [34]. In the complex, benzimidazolium protons $\left(\mathrm{C}^{+}-\mathrm{H}\right)$ and amide protons are cooperatively involved in hydrogen bonding with $\mathrm{H}_{2} \mathrm{PO}_{4}^{-}$. Anthracene, being a fluorophore in $\mathbf{1}$, has the advantage of being considered as a flat hydrophobic fluorophore probe for sensing of anions by the change in intensity due to the photo-induced electron transfer (PET) mechanism.

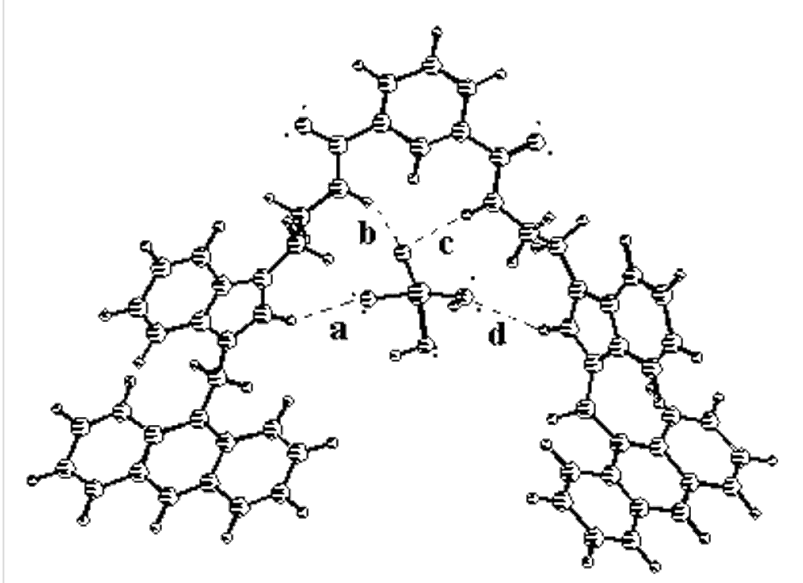

Figure 2: Energy optimized geometry of 1 with $\mathrm{H}_{2} \mathrm{PO}_{4}{ }^{-}(E=92.14$ $\mathrm{kcal} / \mathrm{mol}, a=2.45 \AA, b=1.94 \AA, c=2.34 \AA, d=2.82 \AA$ )

As expected, we observed a change in emission of 1 ( $c=5.78 \times$ $\left.10^{-5} \mathrm{M}\right)$ in $\mathrm{CH}_{3} \mathrm{CN}$ upon the addition of anions as their tetrabutylammonium salts. Receptor $1\left(c=5.78 \times 10^{-5} \mathrm{M}\right)$ in $\mathrm{CH}_{3} \mathrm{CN}$ gave a structured emission band when excited at $369 \mathrm{~nm}$. Upon the addition of 2 equiv of each particular anion to the receptor solution of $\mathbf{1}$, a large change in emission of the anthracene group was observed for $\mathrm{H}_{2} \mathrm{PO}_{4}{ }^{-}$(Figure 3): Other anions perturbed the emission of $\mathbf{1}$ only weakly. Upon the addition of 2 equiv of tetrabutylammonium salts of $\mathrm{H}_{2} \mathrm{PO}_{4}{ }^{-}, \mathrm{F}^{-}$, $\mathrm{Br}^{-}$and $\mathrm{I}^{-}$, the emission of 1 was quenched by 72, 18, 14 and
$30 \%$, respectively. During titration experiments, no other changes such as excimer or exciplex formation were observed. The large quenching in emission of 1 upon increasing $\mathrm{H}_{2} \mathrm{PO}_{4}{ }^{-}$ concentration is illustrated in Figure 4.

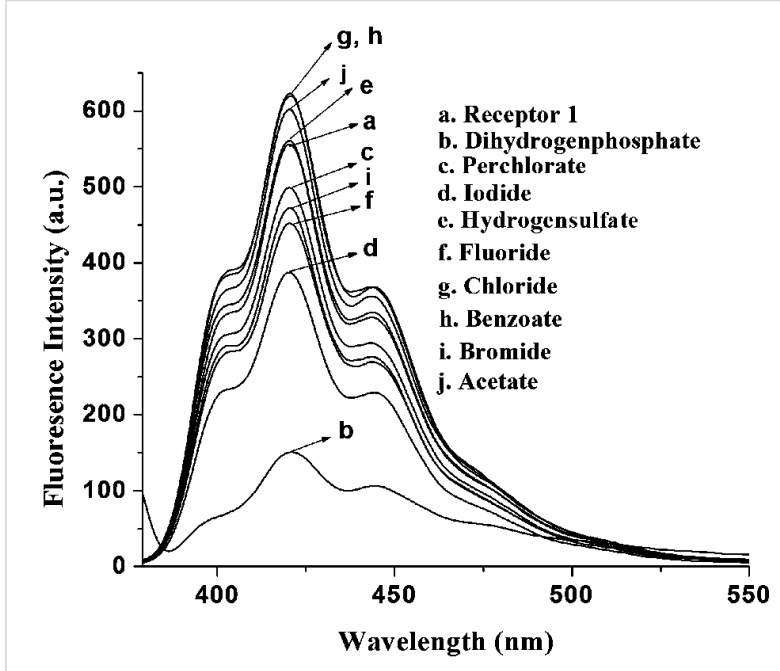

Figure 3: Change in fluorescence emission of $1\left(c=5.78 \times 10^{-5} \mathrm{M}\right)$ in the presence of 2 equiv of tetrabutylammonium salts of different guests in $\mathrm{CH}_{3} \mathrm{CN}$.

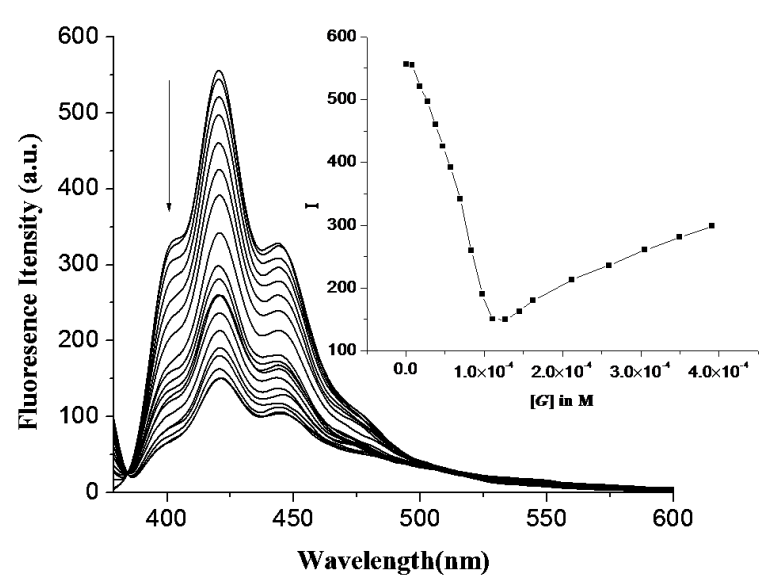

Figure 4: Change in emission spectra of $1\left(c=5.78 \times 10^{-5} \mathrm{M}\right)$ in presence of increasing amounts of $\mathrm{H}_{2} \mathrm{PO}_{4}{ }^{-}$in $\mathrm{CH}_{3} \mathrm{CN}$; Inset: Plot of fluorescence intensity vs concentration of $\mathrm{H}_{2} \mathrm{PO}_{4}{ }^{-}$.

Interestingly, the emission of $\mathbf{1}$ is quenched up to the addition of an equivalent amount of $\mathrm{H}_{2} \mathrm{PO}_{4}{ }^{-}$ions. Further addition caused an increase in emission. This is presumably due to a change in conformation upon complexation or decomplexation of anion, although deprotonation of the bound $\mathrm{H}_{2} \mathrm{PO}_{4}{ }^{-}$cannot be ignored [35]. We believe that initially, the binding sites of $\mathbf{1}$ interact cooperatively to make a $1: 1$ complex according to the suggested mode $\mathbf{A}$, which in turn, changes to mode $\mathbf{B}$ with 2:1 (guest:host) stoichiometry in the presence of excess $\mathrm{H}_{2} \mathrm{PO}_{4}{ }^{-}$(Figure 5). 


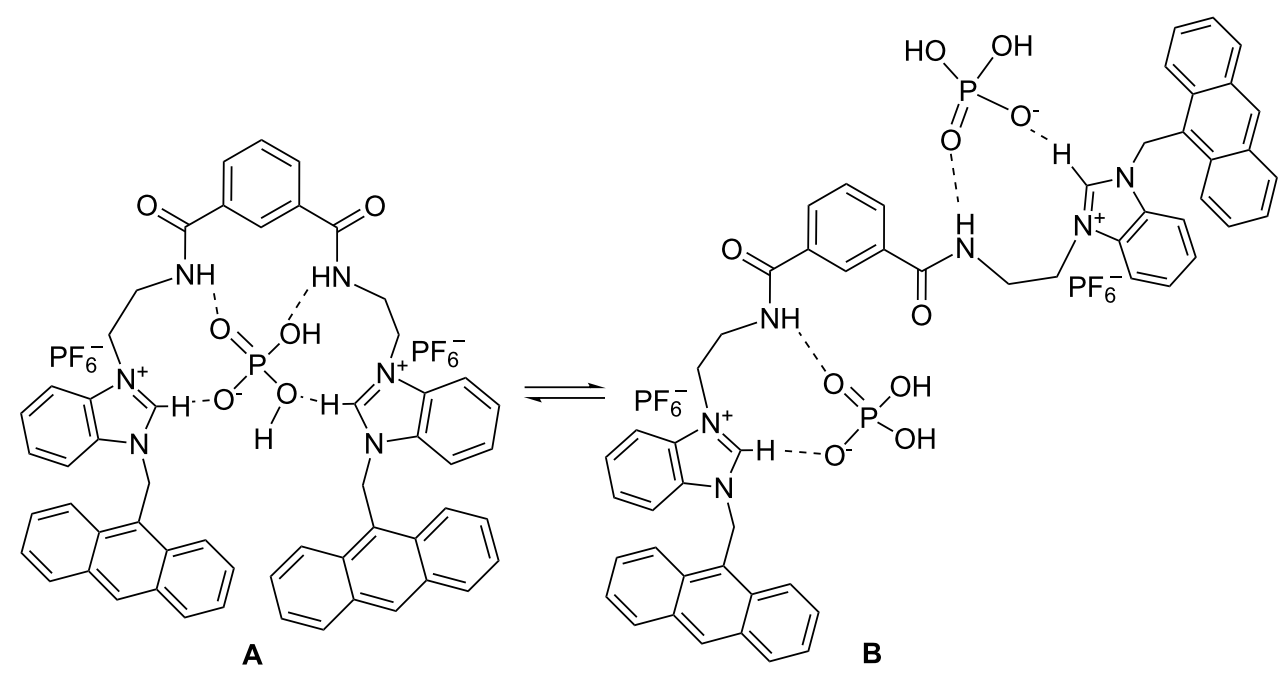

Figure 5: Suggested modes of binding of the $\mathrm{H}_{2} \mathrm{PO}_{4}^{-}$ion into the cleft of 1 .

The flexible nature of the binding site contributes to this aspect. For an example of a related system, see [36]. The stoichiometry of the complexes was confirmed by Job plots (see Supporting Information File 1) as well as from the break of the titration curves at $[G] /[H]=2$ (Figure 6 ).

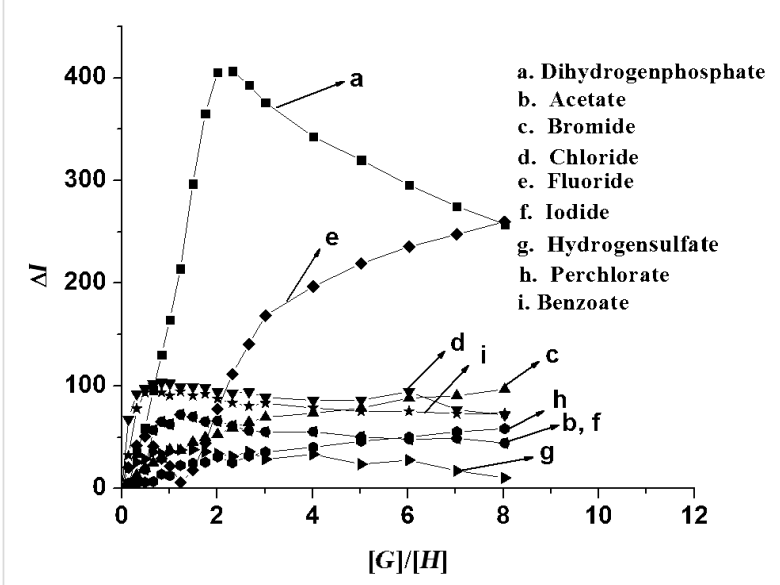

Figure 6: Plot of change in emission of 1 at $420 \mathrm{~nm}$ vs the ratio of guest to host concentration in $\mathrm{CH}_{3} \mathrm{CN}$.

Figure 7, for example, represents the Job plot [37] for $\mathrm{H}_{2} \mathrm{PO}_{4}{ }^{-}$, which corresponds to a clear-cut case for 2:1 stoichiometry of the complex. In the binding process, cooperative interaction of the two benzimidazolium motifs in $\mathbf{1}$ are primarily necessary for a large change in emission. This was proved by considering the model compound $\mathbf{2}$, where only one binding site is present for interaction. Under similar experimental conditions, the emission of 2 was only slightly changed.

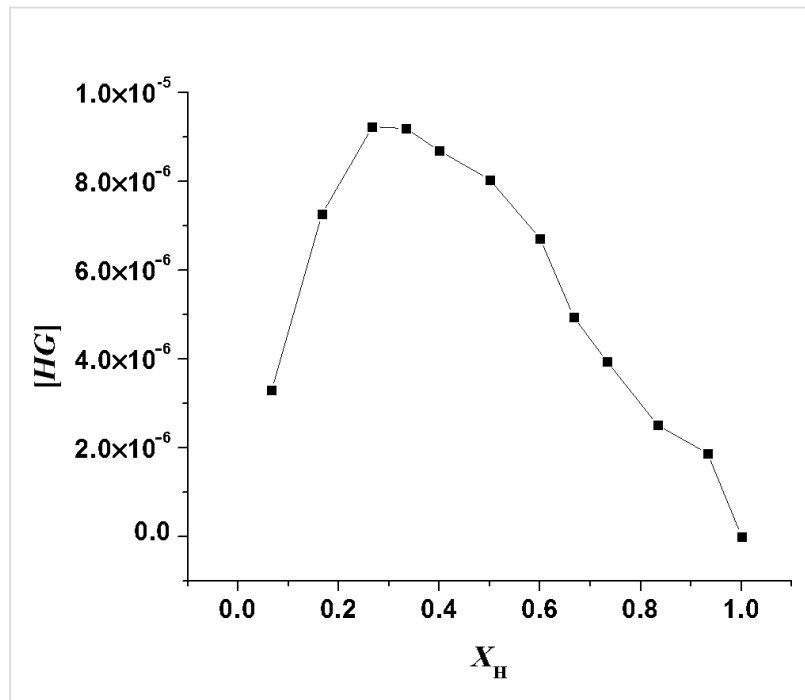

Figure 7: Fluorescence Job plot of 1 with $\mathrm{H}_{2} \mathrm{PO}_{4}{ }^{-}$.

Figure 8 displays the change in emission of 2 upon addition of 1 equiv of the same anions in $\mathrm{CH}_{3} \mathrm{CN}$. In the presence of excess $\mathrm{H}_{2} \mathrm{PO}_{4}{ }^{-}$ions, the change in emission of 2 was less compared to the case of $\mathbf{1}$ (see Supporting Information File 1).

The quenching of emission of $\mathbf{1}$ upon complexation is attributed to the activation of a PET process occurring between the binding site and the excited state of anthracene. The Stern-Volmer plot in Figure 9 illustrates the quenching phenomena with anions such as $\mathrm{H}_{2} \mathrm{PO}_{4}^{-}, \mathrm{F}^{--}, \mathrm{Br}^{-}$and $\mathrm{I}^{-}$. The non-linear nature of the curves in Figure 9 indicates that both static (hydrogen bonding effects) and dynamic quenching (bimolecular collision) take place during binding. 


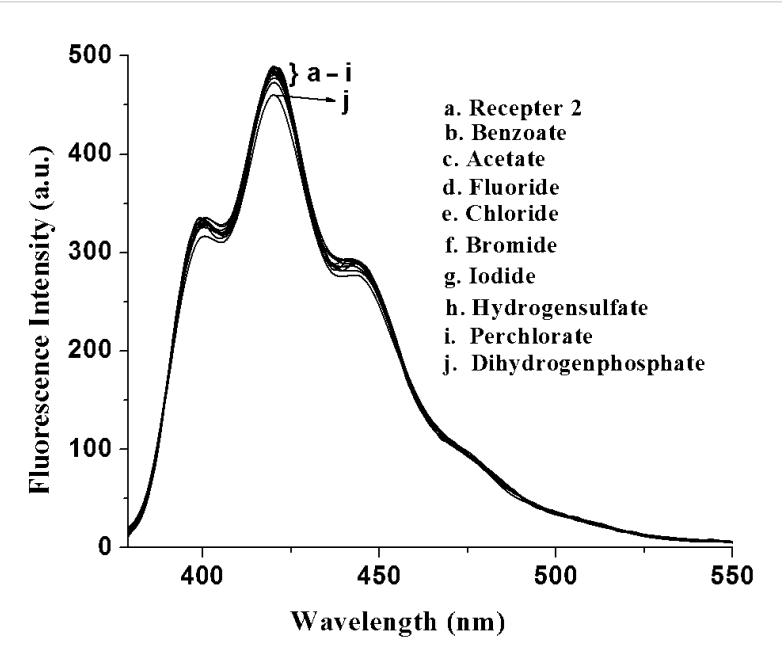

Figure 8: Change in fluorescence emission of $2\left(c=3.93 \times 10^{-5} \mathrm{M}\right)$ in the presence of 1 equiv of tetrabutylammonium salts of different guests in $\mathrm{CH}_{3} \mathrm{CN}$.

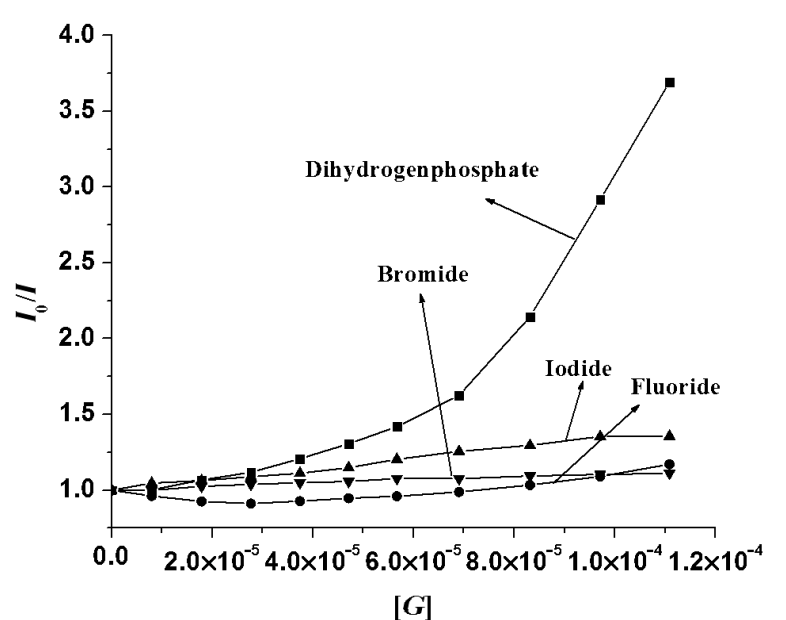

Figure 9: Stern-Volmer plots for $1\left(c=5.78 \times 10^{-5} \mathrm{M}\right)$ with $\mathrm{H}_{2} \mathrm{PO}_{4}{ }^{-}$, $\mathrm{F}^{-}, \mathrm{Br}^{-}$and $\mathrm{I}^{-}$at $420 \mathrm{~nm}$ (up to the addition of 2 equiv of guest) in $\mathrm{CH}_{3} \mathrm{CN}$.
Concurrent UV-vis studies of $\mathbf{1}$ with the anions exhibited only a small change in absorbance of anthracene and predicted $\mathbf{1}$ as a PET system [38]. In many cases, the change of absorbance during the titration with the anions was irregular. Figure 10 corroborates the irregular change in absorbance of $\mathbf{1}$ on titration with $\mathrm{H}_{2} \mathrm{PO}_{4}{ }^{-}$and importantly, in the ground state, all the anions showed 1:1 binding (Supporting Information File 1). However, the selectivity of $\mathbf{1}$ towards the anions studied was established by determining the binding constant values from fluorescence titration data (Table 1) [39]. As can be seen from Table 1, the receptor 1 shows a marginal selectivity for $\mathrm{H}_{2} \mathrm{PO}_{4}{ }^{-}$. The receptor 1 also binds the larger sized iodide ion with 2:1 (guest:host) stoichiometry. By comparison, the change in emission of $\mathbf{1}$ in the presence of the smaller sized $\mathrm{F}^{-}$is attributed to its greater charge density which causes strong hydrogen bonding followed by deprotonation. Although receptor 1 demonstrates a similar order of binding with $\mathrm{F}^{-}, \mathrm{I}^{-}$and $\mathrm{H}_{2} \mathrm{PO}_{4}^{-}$

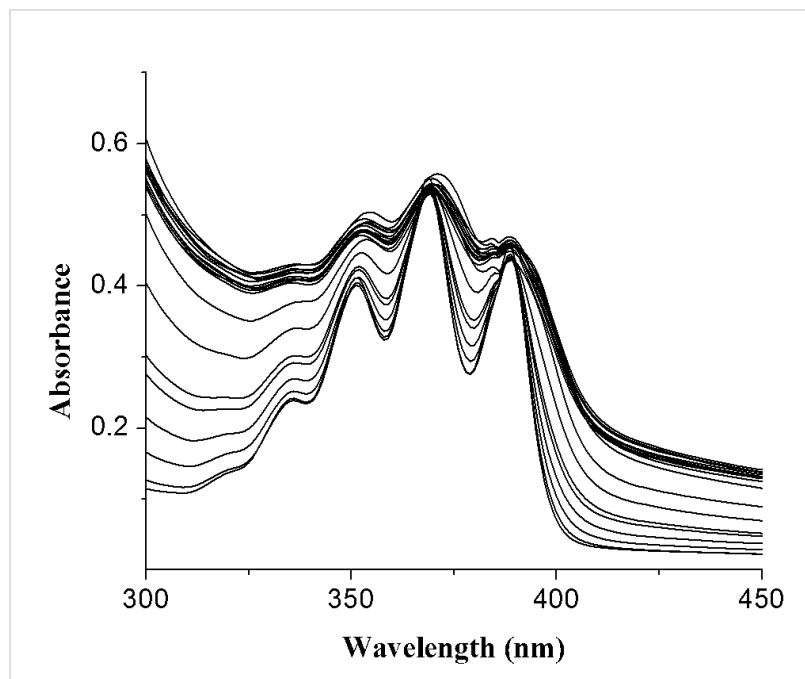

Figure 10: Change in UV-vis spectra of $1\left(c=5.78 \times 10^{-5} \mathrm{M}\right)$ in presence of increasing amounts of $\mathrm{H}_{2} \mathrm{PO}_{4}^{-}$in $\mathrm{CH}_{3} \mathrm{CN}$.

Table 1: Binding constant values of 1 with the guests by fluorescence method.

\begin{tabular}{|c|c|c|}
\hline Guests $^{a}$ & $K_{\mathrm{a}}\left(\mathrm{M}^{-1}\right)^{\mathrm{d}}$ in $\mathrm{CH}_{3} \mathrm{CN}$ & $K_{\mathrm{a}}\left(\mathrm{M}^{-1}\right)^{\mathrm{d}}$ in $\mathrm{CHCl}_{3}$ containing $0.1 \% \mathrm{CH}_{3} \mathrm{CN}$ \\
\hline Acetate & $\_^{b}$ & $-^{b}$ \\
\hline Benzoate & $-^{\mathrm{b}}$ & $-^{b}$ \\
\hline Dihydrogen phosphate & $5.56 \times 10^{3 c}$ & $1.29 \times 10^{4}$ \\
\hline Hydrogen sulfate & $-b$ & $-b$ \\
\hline Perchlorate & $-^{b}$ & $-^{b}$ \\
\hline Fluoride & $4.06 \times 10^{3 c}$ & $-\mathrm{b}$ \\
\hline Chloride & $-\mathrm{b}$ & $-\mathrm{b}$ \\
\hline Bromide & $-\mathrm{b}$ & $5.05 \times 10^{3}$ \\
\hline lodide & $2.41 \times 10^{3 c}$ & $6.90 \times 10^{4}$ \\
\hline
\end{tabular}

aTetrabutylammonium salts were used; b Not determined due to minor change; c Considering $K_{11}$; ${ }^{\mathrm{d}}$ Error: $\leq \pm 10 \%$. 
in $\mathrm{CH}_{3} \mathrm{CN}$, the greater fluorometric change of $\mathbf{1}$ in the presence of $\mathrm{H}_{2} \mathrm{PO}_{4}{ }^{-}$is quite worth mentioning for its fluorometric distinction from other anions in the present study.

For the application of this simple receptor in aqueous system, we carried out the complexation study of 1 in aq $\mathrm{CH}_{3} \mathrm{OH}$ $\left(\mathrm{CH}_{3} \mathrm{OH}: \mathrm{H}_{2} \mathrm{O}=4: 1 \mathrm{v} / \mathrm{v}\right)$ with different phosphate salts. Surprisingly, the change in emission of $\mathbf{1}$ was found to be negligible (see Supporting Information File 1). This suggested weak or no interactions of 1 in aq $\mathrm{CH}_{3} \mathrm{OH}$. However, on changing the polarity of the medium both $\mathbf{1}$ and $\mathbf{2}$ responded more efficiently and behaved differently. When $\mathrm{CH}_{3} \mathrm{CN}$ was replaced by $\mathrm{CHCl}_{3}$ containing $0.1 \% \mathrm{CH}_{3} \mathrm{CN}$, the change in emission of 1 upon complexation of the same anions was very sharp and found to be sharpest for the iodide ion. Figure 11 shows the change in emission of $\mathbf{1}$ in presence of particular anions. The large quenching of emission in the presence of $\mathrm{I}^{-}$is a characteristic feature of $\mathbf{1}$ for the fluorometric identification of $\mathrm{I}^{-}$among the other anions in $\mathrm{CHCl}_{3}$ containing $0.1 \% \mathrm{CH}_{3} \mathrm{CN}$. Iodide is an important halide that plays an important role in several biological processes such as neurological activity and thyroid function. The iodide content of urine and milk is often required to provide information for nutritional, metabolic, and epidemiological studies of thyroid disorder [40]. In relation to this, very few reports on iodide recognition are known in the literature [41-45].

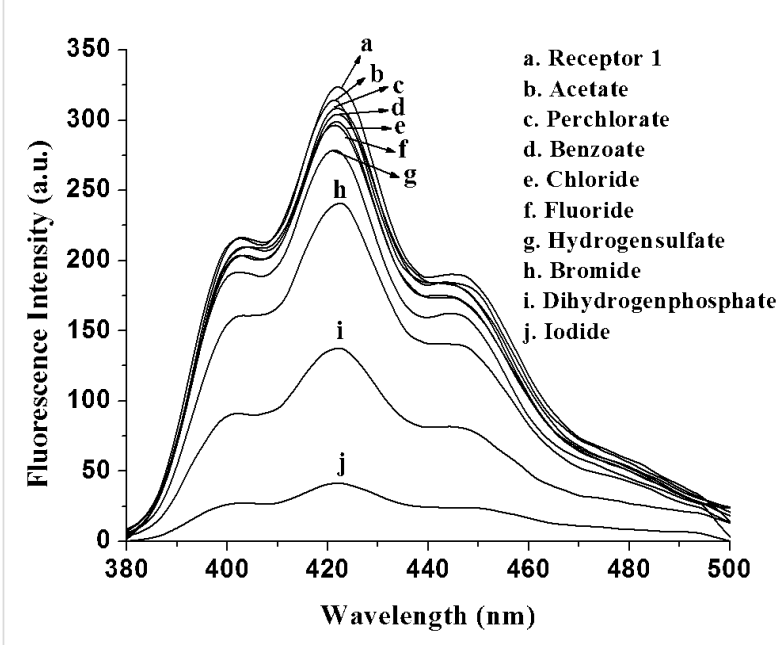

Figure 11: Change in fluorescence emission of $1\left(c=5.78 \times 10^{-5} \mathrm{M}\right)$ in the presence of 2 equiv of tetrabutylammonium salts of different guests in $\mathrm{CHCl}_{3}$ containing $0.1 \% \mathrm{CH}_{3} \mathrm{CN}$.

Iodide binding induced quenching of emission is attributed to the i) complementarity in size of iodide with the pseudocavity formed by the receptor-binding site and ii) heavy atom effect of iodide, which is also true for $\mathrm{Br}^{-}$. But the small quenching of emission in the presence of $\mathrm{Br}^{-}$suggests that $\mathrm{I}^{-}$induced quenching is not only due to the heavy atom effect but also involves some hydrogen bonding effects. Figure 12 is the Stern-Volmer plot of the quenching process. It was also noted that while the monomeric benzimidazolium unit 2 was ineffective in $\mathrm{CH}_{3} \mathrm{CN}$, it showed measurable changes in emission in $\mathrm{CHCl}_{3}$ containing $0.1 \% \mathrm{CH}_{3} \mathrm{CN}$ (Supporting Information File 1). These observations thus intimate that solvent polarity is an important aspect for monitoring the sensing behavior of benzimidazolium-based receptors. In our opinion, $\mathrm{CH}_{3} \mathrm{CN}$ in the present case participates in $\mathrm{H}$-bonding with the polar $\mathrm{C}^{+}-\mathrm{H}$ bond of benzimidazolium motif and reduces the possibility of host-guest interactions [46]. This is clearly reflected in the binding constant values in Table 1. Due to the presence of a minimum amount of $\mathrm{CH}_{3} \mathrm{CN}$ in $\mathrm{CHCl}_{3}$ the binding constant values for the selected anions are greater in magnitude. In the series $\mathrm{I}^{-}$shows a higher value of $K_{\mathrm{a}}$. We presume that it is due to the dimension of the open cavity of $\mathbf{1}$ in $\mathrm{CHCl}_{3}$ containing $0.1 \% \mathrm{CH}_{3} \mathrm{CN}$ for which $\mathrm{I}^{-}$anion fits sterically with $1: 1$ stoichiometry. Other complexes in $\mathrm{CHCl}_{3}$ containing $0.1 \% \mathrm{CH}_{3} \mathrm{CN}$ had also 1:1 stoichiometry.

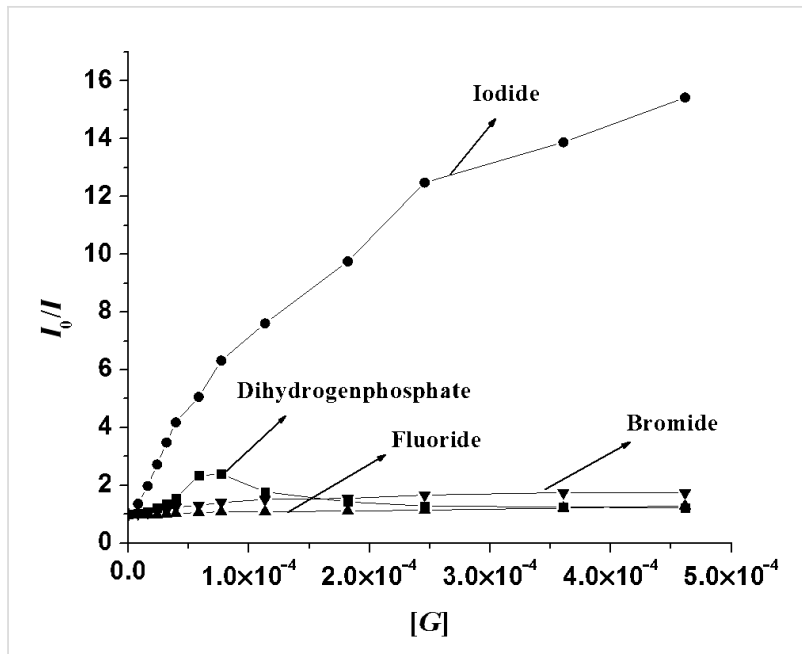

Figure 12: Stern-Volmer plots for $1\left(c=5.78 \times 10^{-5} \mathrm{M}\right)$ with $\mathrm{H}_{2} \mathrm{PO}_{4}{ }^{-}$, $\mathrm{F}^{-}, \mathrm{Br}^{-}$and $\mathrm{I}^{-}$at $420 \mathrm{~nm}$ (up to the addition of 2 equiv of guest) in $\mathrm{CHCl}_{3}$ containing $0.1 \% \mathrm{CH}_{3} \mathrm{CN}$.

Time resolved fluorescence measurements were additionally carried out to study the dynamics of the flexible receptor 1 $\left(\lambda_{\text {exc }}=369 \mathrm{~nm}\right)$ in the presence and absence of the anions such as $\mathrm{H}_{2} \mathrm{PO}_{4}{ }^{-}$in $\mathrm{CH}_{3} \mathrm{CN}$. The emission decay profile of 1 monitored at $420 \mathrm{~nm}$ could be fitted bi-exponentially with two constants $\tau_{1}=3.42 \mathrm{~ns}(12.22 \%), \tau_{2}=7.76 \mathrm{~ns}(87.78 \%)$. The faster decay component (3.42 ns) is due to the anthracene moiety [47] and the relatively stable component with longer lifetime $(7.76 \mathrm{~ns})$ is attributed to the benzimidazolium motif of 1. However, in the presence of 1 equiv of $\mathrm{H}_{2} \mathrm{PO}_{4}{ }^{-}$, the lifetime of both the components marginally decreases (Table 2 ). In the 
Table 2: Fluorescence decay times ( $\mathrm{T}$ ) and pre-exponential factors (c) for 1 in the presence and absence of anions

\begin{tabular}{lllll} 
& $\mathrm{T}_{1}(\mathrm{c})$ & $\mathrm{T}_{2}(\mathrm{c})$ & $\mathrm{T}_{3}(\mathrm{c})$ & $\mathrm{X}^{2}$ \\
\hline Receptor 1a & $3.42 \mathrm{~ns}(12.22 \%)$ & $7.76 \mathrm{~ns}(87.78 \%)$ & - & 1.13 \\
$\mathbf{1}+\mathrm{Bu}_{4} \mathrm{~N}^{+} \mathrm{H}_{2} \mathrm{PO}_{4}^{-}(1: 1)^{\mathrm{a}}$ & $3.36 \mathrm{~ns}(11.40 \%)$ & $7.72 \mathrm{~ns} \mathrm{(88.60 \% )}$ & - & 1.18 \\
$\mathbf{1}+\mathrm{Bu}_{4} \mathrm{~N}^{+} \mathrm{H}_{2} \mathrm{PO}_{4}^{-}(1: 2)^{\mathrm{a}}$ & $3.49 \mathrm{~ns}(11.74 \%)$ & $7.75 \mathrm{~ns}(88.26 \%)$ & - & 1.13 \\
Receptor 1 $^{\mathrm{b}}$ & $1.45 \mathrm{~ns}(2 \%)$ & $8.90 \mathrm{~ns}(98 \%)$ & - & 1.12 \\
$\mathbf{1}+\mathrm{Bu}_{4} \mathrm{~N}^{+} I^{-}(1: 1)^{\mathrm{b}}$ & $2.15 \mathrm{~ns}(5.82 \%)$ & $8.95 \mathrm{~ns}(92.86 \%)$ & $0.28 \mathrm{~ns}(1.32 \%)$ & 1.10 \\
\hline
\end{tabular}

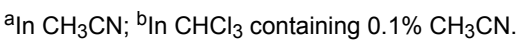

presence of 2 equiv of $\mathrm{H}_{2} \mathrm{PO}_{4}^{-}$, the lifetime of the anthracene component increases without showing any marked change in the pre-exponential factor. This was also true for the benzimidazolium component. Figure 13 shows the decay profiles. The change in the lifetimes of the components in $\mathbf{1}$ in the presence of $\mathrm{H}_{2} \mathrm{PO}_{4}{ }^{-}$ions can be correlated with the change in emission intensity in Figure 4. The fluorescence dynamics of $\mathbf{1}$ was also carried out for $\mathbf{1}$ in the presence and absence of $\mathrm{I}^{-}$in $\mathrm{CHCl}_{3}$ containing $0.1 \% \mathrm{CH}_{3} \mathrm{CN}$. On changing the solvent combination, the lifetimes of the anthracene and benzimidazolium components of 1 changed (Table 2). Interestingly, while the faster decay component $(1.45 \mathrm{~ns})$ due to anthracene moiety contributed a small pre-exponential factor $(2 \%)$, the relatively stable benzimidazolium component ( $8.90 \mathrm{~ns})$ had a larger contribution $(98 \%)$ to the total emission of the molecule. However, upon addition of equivalent amounts of $\mathrm{I}^{-}$the decay profile followed a tri-exponential fitting that indicated three emitting species with lifetimes $\tau_{1}=2.15 \mathrm{~ns}(5.82 \%)$, $\tau_{2}=8.95 \mathrm{~ns}(92.86 \%)$ and $\tau_{3}=0.28 \mathrm{~ns}(1.32 \%)$ (Figure 14). A small increase in the lifetimes of both the anthracene and benzimidazolium moieties in $\mathbf{1}$ is attributed to the formation of

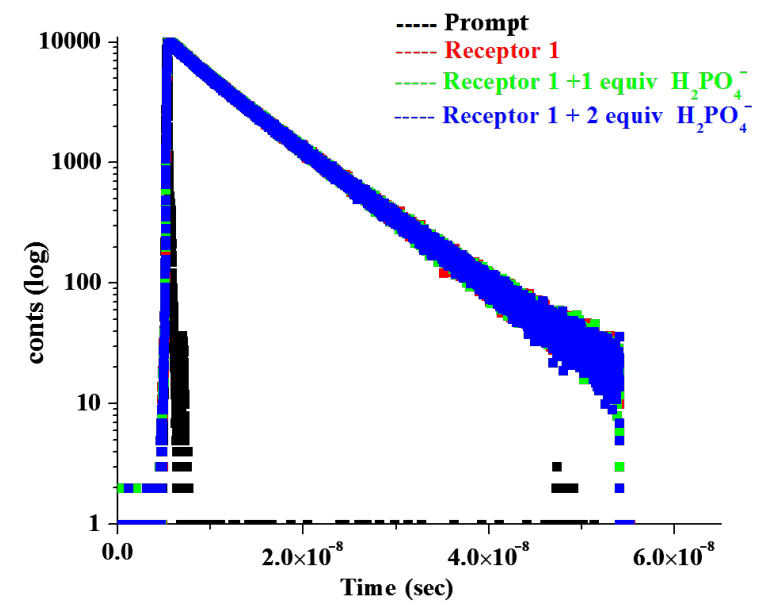

Figure 13: Fluorescence decays (at $\lambda_{\max }=420 \mathrm{~nm}$ ) of receptor 1 upon the addition of $\mathrm{H}_{2} \mathrm{PO}_{4}^{-}$ion $\left([H]=5.78 \times 10^{-5} \mathrm{M},[\mathrm{G}]=4.33 \times 10^{-3} \mathrm{M}\right)$ in $\mathrm{CH}_{3} \mathrm{CN}$ solvent. hydrogen bonds with $\mathrm{I}^{-}$in the open cavity of $\mathbf{1}$. The faster decay component $(0.28 \mathrm{~ns})$ is assumed to be either due to a very short-lived species or an artifact or for tunneling of extra energy to the bulk by a non-radiative pathway $[47,48]$.

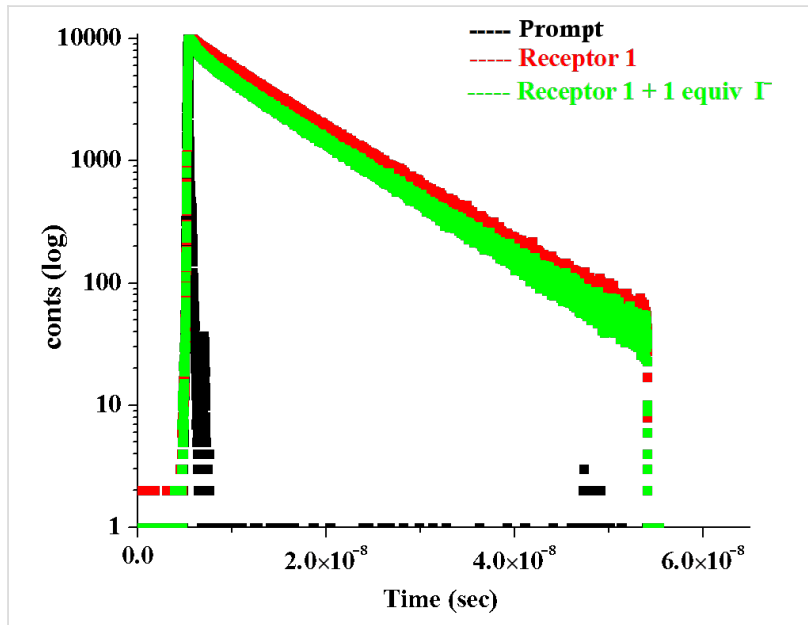

Figure 14: Fluorescence decays (at $\lambda_{\max }=420 \mathrm{~nm}$ ) of receptor 1 upon the addition of $\mathrm{I}^{-}$ion $\left([H]=5.78 \times 10^{-5} \mathrm{M},[\mathrm{G}]=4.55 \times 10^{-3} \mathrm{M}\right)$ in $\mathrm{CHCl}_{3}$ containing $0.1 \% \mathrm{CH}_{3} \mathrm{CN}$.

The expected strong interaction of 1 with $\mathrm{H}_{2} \mathrm{PO}_{4}{ }^{-}$was established additionally by ${ }^{1} \mathrm{H}$ NMR. Although the guest is primarily bound by the benzimidazolium motif on account of a charge-charge interaction, there is undoubtedly a degree of cooperation from the amide protons as evidenced by the downfield change in their chemical shift positions in ${ }^{1} \mathrm{H}$ NMR. Figure 15 indicates the change in chemical shift of the interacting amides and benzimidazolium protons upon complexation of $\mathrm{H}_{2} \mathrm{PO}_{4}{ }^{-}$ions and shows the broadening of the signals of 1 in the ${ }^{1} \mathrm{H}$ NMR spectrum. A precipitate appeared during the course of the study due to insolubility in the NMR concentration range and this was one reason for not determining the binding constant values by the NMR method. However, both the amide and benzimidazolium protons $(0.51 \mathrm{ppm})$ were found to move downfield and thereby supported our binding proposition as indicated in Figure 5. The exact position of amide protons $\mathrm{H}_{\mathrm{a}}$ was difficult to determine upon complexation. 
Hydrogen bonding and deprotonation of $\mathbf{1}$ in the presence of $\mathrm{F}^{-}$ was also evidenced from ${ }^{1} \mathrm{H}$ NMR (Supporting Information File 1, Figure 11S). In the presence of 1 equiv of $\mathrm{F}^{-}$the benzimidazolium protons in $\mathbf{1}$ moved downfield by $0.30 \mathrm{ppm}$ which became $0.59 \mathrm{ppm}$ when 2 equiv of $\mathrm{F}^{-}$were added to the receptor solution.

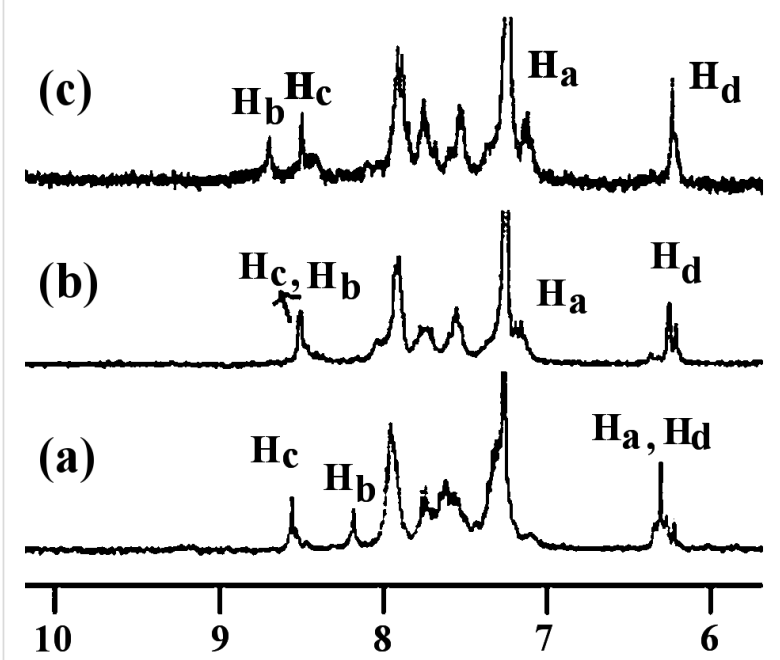

Figure 15: Partial ${ }^{1} \mathrm{H} \mathrm{NMR}\left(300 \mathrm{MHz}, \mathrm{CDCl}_{3}\right.$ containing $\left.4 \% \mathrm{CD}_{3} \mathrm{CN}\right)$ spectra of (a) 1 ( $c=1.38 \times 10^{-3} \mathrm{M}$ ), (b) $1: 1$ and (c) 2:1 (guest:host) complexes with $\mathrm{H}_{2} \mathrm{PO}_{4}^{-}$[see labeled structure 1].

\section{Conclusion}

In conclusion, we have designed a new type of flexible receptor 1, which uniquely responses the recognition of $\mathrm{H}_{2} \mathrm{PO}_{4}{ }^{-}$and $\mathrm{I}^{-}$ by exhibiting large quenching of emission of anthracene group in solvents of different polarities. Two benzimidazolium motifs with an isophthaloyl spacer group in $\mathbf{1}$, act cooperatively for successful detection of $\mathrm{H}_{2} \mathrm{PO}_{4}{ }^{-}$in $\mathrm{CH}_{3} \mathrm{CN}$. In comparison, under the same experimental condition, a single benzimidazolium unit in 2 is inefficient in sensing $\mathrm{H}_{2} \mathrm{PO}_{4}{ }^{-}$ion. By contrast, in the less polar solvent $\mathrm{CHCl}_{3}$ containing $0.1 \%$ $\mathrm{CH}_{3} \mathrm{CN}$, the receptor shows a greater fluorescence quenching for $\mathrm{I}^{-}$. Such differential quenching of $\mathbf{1}$ in the presence of $\mathrm{H}_{2} \mathrm{PO}_{4}{ }^{-}$and $\mathrm{I}^{-}$in different solvent combinations is presumably due to the activation of the PET process occurring between the binding site and the excited state of anthracene function at the different rates. We believe at present that the different degrees of solvation of the anions as well as the effective dimension of the binding site which in turn, controls the selectivity in binding process in the excited state are the key factors that regulate the PET to different extents. The binding affinity and selectivity of this simple fluororeceptor are associated with the combined effects of semi-rigid structures of receptor, charge-charge interactions, and the involvement of both $\mathrm{N}-\mathrm{H}---\mathrm{O}$ and $\mathrm{C}-\mathrm{H}---\mathrm{O}$ hydrogen bonds. Further work is underway in our laboratory.

\section{Experimental}

\section{General methods}

Solvents were distilled prior to use, and dried according to the literature procedure when required. Chromatographic separations were performed on silica gel (60-120 mesh). All melting points were determined in open capillaries and are uncorrected. ${ }^{1} \mathrm{H}$ NMR spectra were recorded on Bruker 400 and $300 \mathrm{MHz}$ spectrometers. ${ }^{13} \mathrm{C}$ NMR spectra were recorded on a Bruker $400 \mathrm{MHz}$ spectrometer. FT IR spectra were recorded on a Perkin-Elmer L120-00A spectrometer as $\mathrm{KBr}$ discs. UV-vis spectra were recorded on Perkin-Elmer Lambda-25 and fluorescence spectra on a Perkin-Elmer LS 55 spectrofluorometer, respectively.

\section{Synthesis of 3 [49]}

To a solution of benzimidazole $(0.300 \mathrm{~g}, 2.54 \mathrm{mmol})$ in dry THF $(15 \mathrm{~mL})$, NaH $(0.14 \mathrm{~g})$ was added and the mixture refluxed for $1 \mathrm{~h}$ under a nitrogen atmosphere. The reaction mixture was then cooled to room temperature, 9-chloromethylanthracene $(0.700 \mathrm{~g}, 3.09 \mathrm{mmol})$ in THF $(15 \mathrm{~mL})$ added and then heated under reflux for $10 \mathrm{~h}$. The THF was removed, water added and the mixture extracted with $\mathrm{CHCl}_{3}(3 \times 30 \mathrm{~mL})$. The organic layer was dried over anhydrous $\mathrm{Na}_{2} \mathrm{SO}_{4}$ and concentrated on a rotary evaporator. Purification of the crude product by silica gel column chromatography with $20 \%$ ethyl acetate in petroleum ether as eluent gave compound $3(0.500 \mathrm{~g}$, yield 64\%). ${ }^{1} \mathrm{H} \mathrm{NMR}$ in $\mathrm{CDCl}_{3}(400 \mathrm{MHz}) \delta 8.61(\mathrm{~s}, 2 \mathrm{H}), 8.10(\mathrm{~d}$, $4 \mathrm{H}, J=8 \mathrm{~Hz}), 7.82(\mathrm{~d}, 1 \mathrm{H}, J=8 \mathrm{~Hz}), 7.71$ (d, $1 \mathrm{H}, J=8 \mathrm{~Hz})$, $7.51(\mathrm{~m}, 4 \mathrm{H}), 7.42(\mathrm{t}, 1 \mathrm{H}, J=8 \mathrm{~Hz}), 7.35(\mathrm{t}, 1 \mathrm{H}, J=8 \mathrm{~Hz}), 6.19$ $(\mathrm{s}, 2 \mathrm{H}) ;{ }^{13} \mathrm{C} \mathrm{NMR}\left(\mathrm{CDCl}_{3}, 100 \mathrm{MHz}\right) \delta 144.0,142.2,134.2$, $131.4,131.0,129.7,129.5,127.5,125.4,123.6,123.1,123.0$, 122.5, 120.6, 109.5, 41.3; m/z $\left(\mathrm{ES}^{+}\right): 308.9[\mathrm{M}]^{+}$.

\section{Synthesis of 4}

A mixture of 2-chloroethylamine hydrochloride (704 mg, $6 \mathrm{mmol})$ in dry $\mathrm{CH}_{2} \mathrm{Cl}_{2}(30 \mathrm{~mL})$ containing triethylamine $(1.35 \mathrm{~mL})$ was stirred for $1 \mathrm{~h}$ to give the free amine. To this solution, isophthaloyl dichloride (600 $\mathrm{mg}, 2.9 \mathrm{mmol}$ ) was added and the reaction mixture stirred at room temperature for $8 \mathrm{~h}$. The solvent was evaporated and water added. The aqueous layer was extracted with $\mathrm{CHCl}_{3}(3 \times 50 \mathrm{~mL})$, the combined organic phases was washed with water, dried over anhydrous $\mathrm{Na}_{2} \mathrm{SO}_{4}$ and concentrated in vacuo. The resulting crude solid was purified by column chromatography with $50 \%$ ethyl acetate in petroleum ether as eluent to give pure $4(0.67 \mathrm{~g}$, yield $78 \%), \mathrm{mp}$ $145{ }^{\circ} \mathrm{C},{ }^{1} \mathrm{H} \mathrm{NMR}\left(\mathrm{CDCl}_{3}, 400 \mathrm{MHz}\right): \delta 8.25(\mathrm{~s}, 1 \mathrm{H}), 7.94(\mathrm{dd}$, $\left.2 \mathrm{H}, J_{1}=8 \mathrm{~Hz}, J_{2}=4 \mathrm{~Hz}\right), 7.53(\mathrm{t}, 1 \mathrm{H}, J=8 \mathrm{~Hz}), 6.84(\mathrm{br} \mathrm{t}, 2 \mathrm{H}$, -NH-), 3.84-3.79 (m, 4H), 3.75-3.71 (m, 4H); ${ }^{13} \mathrm{C} \mathrm{NMR}$ $\left(\mathrm{CDCl}_{3}\right.$ containing few drops DMSO- $\left.d_{6}, 100 \mathrm{MHz}\right) \delta 166.0$, 134.21, 129.8, 128.3, 126.2, 42.8, 41.3; FTIR: $v \mathrm{~cm}^{-1}(\mathrm{KBr})$ : 3288, 3066, 2915, 2863, 1639, 1539; m/z (LCMS): $289(\mathrm{M})^{+}$. 


\section{Synthesis of 1}

To a stirred solution of $4(0.1 \mathrm{~g}, 3.8 \mathrm{mmol})$ in dry $\mathrm{CH}_{3} \mathrm{CN}(20$ $\mathrm{mL})$, compound $3(0.236 \mathrm{~g}, 7.6 \mathrm{mmol})$ was added and the reaction mixture heated under reflux for 3 days. During the heating the dichloride salt 5 precipitated and was removed by filtration. Repeated recrystallization of the salt from $\mathrm{CH}_{3} \mathrm{CN}$ gave almost pure $5(0.184 \mathrm{~g}, 59.7 \%$ yield $)$. Compound $5(0.184 \mathrm{~g})$ was then dissolved in hot $\mathrm{CH}_{3} \mathrm{OH}(20 \mathrm{~mL})$ followed by addition of $\mathrm{NH}_{4} \mathrm{PF}_{6}$. After stirring the reaction mixture for $30 \mathrm{~min}$, the $\mathrm{CH}_{3} \mathrm{OH}$ was evaporated to reduce the volume. The precipitated salt was filtered, washed with cold water and dried. Repeated recrystallization of 1 from $\mathrm{CH}_{3} \mathrm{CN}$ afforded the pure $\mathbf{1}(0.21 \mathrm{~g}$, $90 \%$ yield), mp $210{ }^{\circ} \mathrm{C},{ }^{1} \mathrm{H}$ NMR (DMSO- $d_{6}, 400 \mathrm{MHz}$ ): $\delta 8.94$ $(\mathrm{s}, 2 \mathrm{H}), 8.83(\mathrm{~s}, 2 \mathrm{H}), 8.50-8.10(\mathrm{~m}, 14 \mathrm{H}), 7.78-7.72(\mathrm{~m}, 4 \mathrm{H})$, $7.59-7.49(\mathrm{~m}, 12 \mathrm{H}), 6.63(\mathrm{~s}, 4 \mathrm{H}), 4.46$ (br s, 4H), 3.59 (br s, $4 \mathrm{H})$ [due to solubility problem signals were broad in nature]; ${ }^{13} \mathrm{C}$ NMR (DMSO- $d_{6}, 100 \mathrm{MHz}$ ): 141.8, 134.3, 132.2, 132.0, $131.5,131.47,131.43,131.1,130.8,129.7,128.2,128.1,127.3$, $127.1,126.0,125.9,123.7,122.0,114.6,114.1,47.0,43.7$, 38.7; FTIR: $v \mathrm{~cm}^{-1}(\mathrm{KBr}): 3433,3146,2954,1721,1652,1565$, $1531 ; \mathrm{m} / \mathrm{z}\left(\mathrm{ES}^{+}\right): 1123.7(\mathrm{M}-1)^{+}, 979.5\left[\left(\mathrm{M}-\mathrm{PF}_{6}{ }^{-}\right)\right]^{+}$.

\section{Synthesis of 2}

A mixture of 2-chloroethylamine hydrochloride (460 mg, 3.9 $\mathrm{mmol})$ in dry $\mathrm{CH}_{2} \mathrm{Cl}_{2}(20 \mathrm{~mL})$ containing triethylamine $(1 \mathrm{~mL})$ was stirred at room temperature for $1 \mathrm{~h}$ to give the free amine. Acetyl chloride $(0.582 \mathrm{~mL}, 5.9 \mathrm{mmol})$ was added to the reaction mixture which was then stirred at room temperature for $8 \mathrm{~h}$. After completion of the reaction, the solvent was evaporated and the residue extracted with $\mathrm{CHCl}_{3}(3 \times 20 \mathrm{~mL})$. The organic extracts were washed with $\mathrm{NaHCO}_{3}$ solution $(3 \times 15 \mathrm{~mL})$ and dried over anhydrous $\mathrm{Na}_{2} \mathrm{SO}_{4}$. The solvent was removed under vacuum and the residue purified by silica gel column chromatography with $80 \%$ ethyl acetate in petroleum ether as eluent to afford the compound 6 (0.309 g, 64\% yield). The chloro-amide $6(150 \mathrm{mg}, 1.2 \mathrm{mmol})$ was heated under reflux in dry $\mathrm{CH}_{3} \mathrm{CN}$ $(20 \mathrm{~mL})$ with the anthracene-coupled benzimidazole $3(570 \mathrm{mg}$, $1.85 \mathrm{mmol})$ for 4 days. The precipitated chloride salt was filtered, washed with water and dried $(0.51 \mathrm{~g}, 64.4 \%)$. The compound 6 in $\mathrm{MeOH}$ was subsequently treated with aqueous $\mathrm{NH}_{4} \mathrm{PF}_{6}$ solution to carry out the anion exchange reaction. The solution was heated with stirring for 20 min until a precipitate appeared. Filtration of the precipitate followed by thorough washing with ether afforded compound 2 in $95 \%$ yield $(0.61 \mathrm{~g})$, mp $203{ }^{\circ} \mathrm{C}$ (decomposition); ${ }^{1} \mathrm{H}$ NMR (DMSO- $d_{6}, 400 \mathrm{MHz}$ ): $\delta$ 8.93 (s, 1H), 8.82 (s, 1H), 8.41 (d, 1H, $J=8 \mathrm{~Hz}), 8.33$ (d, 2H, $J$ $=8 \mathrm{~Hz}), 8.27(\mathrm{~d}, 2 \mathrm{H}, J=8 \mathrm{~Hz}), 8.08(\mathrm{~d}, 1 \mathrm{H}, J=8 \mathrm{~Hz})$ 7.84-7.78 (m, 2H), 7.63 (br m, 5H), 6.67 (s, 2H), 4.32 (br s, 2H), 3.50 (br s, 2H), 2.32 (s, 3H); ${ }^{13} \mathrm{C}$ NMR (DMSO- $d_{6}, 100$ MHz): 169.4, 141.2, 131.8, 131.4, 131.1, 131.0, 130.4, 129.3, $127.8,126.8,126.6,125.6,123.3,121.5,114.2,113.5,57.4$,
46.4, 43.2, 37.2; FTIR: $v \mathrm{~cm}^{-1}(\mathrm{KBr}): 3436,1718,1654,1563$, 1453. $\mathrm{m} / \mathrm{z}$ (LCMS): $394.2\left[\left(\mathrm{M}-\mathrm{PF}_{6}{ }^{-}\right)\right]^{+}$.

\section{General procedure of fluorescence and UV-vis titrations:}

Stock solutions of the receptors were prepared in different solvents such as $\mathrm{CH}_{3} \mathrm{CN}$ and $\mathrm{CHCl}_{3}$ containing $0.1 \% \mathrm{CH}_{3} \mathrm{CN}$ and $2.5 \mathrm{ml}$ of the individual receptor solution was placed in the cuvette. Stock solutions of anions were prepared in the same solvents, and were added individually in different amounts to the receptor solution. For fluorescence, the receptor solutions prepared in dry $\mathrm{CH}_{3} \mathrm{CN}$ were irradiated at the excitation wavelength $369 \mathrm{~nm}$ maintaining the excitation and emission slits 8 and 8 , respectively and the filter was $1 \%$ attenuated. Upon the addition of anions, the change in emission and absorbance of the receptors were noted. Similarly, for emission, the receptors dissolved in $\mathrm{CHCl}_{3}$ containing $0.1 \% \mathrm{CH}_{3} \mathrm{CN}$ were irradiated at the excitation wavelength $369 \mathrm{~nm}$ maintaining the excitation and emission slits 10 and 5 , respectively.

Method for Job plots: The stoichiometry was determined by the continuous variation method (Job Plot) [35]. In this method, solutions of host and guests of equal concentrations were prepared in dry $\mathrm{CH}_{3} \mathrm{CN}$ and $\mathrm{CHCl}_{3}$ containing $0.1 \% \mathrm{CH}_{3} \mathrm{CN}$. Then the host and guest solutions were mixed in different proportions maintaining a total volume of $3 \mathrm{~mL}$ of the mixture. The related compositions for host:guest $(v / v)$ were $3: 0,2.8: 0.2$, $2.5: 0.5,2.2: 0.8,2: 1,1.8: 1.2,1.5: 1.5,1: 2,0.8: 2.2,0.5: 2.5$, $0.2: 2.8$. All the prepared solutions were kept for $1 \mathrm{~h}$ at room temperature with occasional shaking. Then the emission and absorbance of the solutions of different compositions was recorded. The concentration of the complex, i.e., $[H G]$ was calculated using the equation $[H G]=\Delta I / I_{0} \times[H]$ or $[H G]=\Delta A /$ $A_{0} \times[H]$ where $\Delta I / I_{0}$ and $\Delta A / A_{0}$ indicate the relative emission and absorbance intensities. $[H]$ corresponds to the concentration of pure host. The mole fraction of the host $\left(X_{\mathrm{H}}\right)$ was plotted against the concentration of the complex $[H G]$. In the plot, the mole fraction of the host at which the concentration of the host-guest complex concentration $[H G]$ is maximum, gives the stoichiometry of the complex.

\section{Supporting Information}

\section{Supporting Information File 1}

Supplementary Data.

[http://www.beilstein-journals.org/bjoc/content/

supplementary/1860-5397-7-34-S1.pdf]

\section{Acknowledgements}

We thank CSIR, Government of India for financial support. K.G. thanks DST, Government of India for providing facilities 
in the department under FIST program and also to UGC for the SAP program. D. K. thanks CSIR, New Delhi, India for providing fellowship.

\section{References}

1. Spichiger-Keller, U. E. Chemical Sensors and Biosensors for Medical and Biological Applications; Wiley-VCH: Weinheim, Germany, 1998. doi:10.1002/9783527612284

2. Steed, J. W. Chem. Commun. 2006, 2637-2649. doi:10.1039/b601511e

3. Martínez-Máñez, R.; Sancenón, F. Chem. Rev. 2003, 103, 4419-4476. doi:10.1021/cr010421e

4. Caltagirone, C.; Gale, P. A. Chem. Soc. Rev. 2009, 38, 520-538. doi:10.1039/b806422a

5. Gale, P. A.; García-Garrido, S. E.; Garric, J. Chem. Soc. Rev. 2008, 37, 151-190. doi:10.1039/b715825d

6. Sessler, J. L.; Barkey, N. M.; Pantos, G. D.; Lynch, V. M. New J. Chem. 2007, 31, 646-654. doi:10.1039/b615673h

7. Ullmann's encyclopedia of industrial chemistry, 6th ed.; Wiley-VCH: Weinheim, Germany, 2002.

8. Kirk, K. L. Biochemistry of the Elemental Halogens and Inorganic Halides; Plenum Press: New York, NY, 1991; p 591.

9. Rurack, K.; Resch-Genger, U. Chem. Soc. Rev. 2002, 31, 116-127. doi:10.1039/b100604p

10. Tajc, S. G.; Miller, B. L. J. Am. Chem. Soc. 2006, 128, 2532-2533. doi:10.1021/ja058126p

11. James, T. D.; Sandanayake, K. R. A. S.; Shinkai, S. Angew. Chem., Int. Ed. Engl. 1994, 33, 2207-2209. doi:10.1002/anie.199422071

12. Khalil, M. M. H.; De Schryver, F. C.; Keller, H.; Lehn, J.-M. Supramol. Sci. 1995, 2, 175-182. doi:10.1016/0968-5677(96)89673-8

13. Vance, D. H.; Czarnik, A. W. J. Am. Chem. Soc. 1994, 116, 9397-9398. doi:10.1021/ja00099a094

14. Lankshear, M. D.; Beer, P. D. Coord. Chem. Rev. 2006, 250, 3142-3160. doi:10.1016/j.ccr.2006.04.018

15. Blondean, P.; Benet-Buchholz, J.; de Mendoza, J. New J. Chem. 2007, 31, 736-740. doi:10.1039/b616409a

And references cited therein

16. Ghosh, K.; Adhikari, S. Tetrahedron Lett. 2006, 47, 8165-8169. doi:10.1016/j.tetlet.2006.09.035

And references cited therein.

17. Chang, K.-J.; Moon, D.; Lah, M. S.; Jeong, K.-S. Angew. Chem., Int. Ed. 2005, 44, 7926-7929. doi:10.1002/anie.200503121

18. Caltagirone, C.; Gale, P. A.; Hiscock, J. R.; Brooks, S. J.; Hursthouse, M. S.; Light, M. E. Chem. Commun. 2008, 3007-3009. doi:10.1039/b806238b

19. Caltagirone, C.; Hiscock, J. R.; Hursthouse, M. B.; Light, M. E.; Gale, P. A. Chem.-Eur. J. 2008, 14, 10236-10243. doi:10.1002/chem.200801639

20. Gale, P. A. Chem. Commun. 2005, 3761-3772. doi:10.1039/b504596g

21. Schmuck, C.; Machon, U. Eur. J. Org. Chem. 2006, 4385-4392. doi:10.1002/ejoc.200600324

22. Yoon, J.; Kim, S. K.; Singh, N. J.; Kim, K. S. Chem. Soc. Rev. 2006, 35, 355-360. doi:10.1039/b513733k

23. Bai, Y.; Zhang, B.-G.; Xu, J.; Duan, C.-Y.; Dang, D.-B.; Liu, D.-J.; Meng, Q.-J. New J. Chem. 2005, 29, 777-779. doi:10.1039/b500252d

24. Bai, Y.; Zhang, B.-G.; Duan, C.-Y.; Dang, D.-B.; Meng, Q.-J. New J. Chem. 2006, 30, 266-271. doi:10.1039/b508173d
25. Ghosh, K.; Saha, I.; Patra, A. Tetrahedron Lett. 2009, 50, 2392-2397. doi:10.1016/j.tetlet.2009.02.215

And references cited therein.

26. Gong, W.; Hiratani, K. Tetrahedron Lett. 2008, 49, 5655-5657. doi:10.1016/j.tetlet.2008.07.078

27. Kondo, S.-I.; Hiraoka, Y.; Kurumatani, N.; Yano, Y. Chem. Commun. 2005, 1720-1722. doi:10.1039/B417304J

28. Guo, D.-S.; Liu, Z.-P.; Ma, J.-P.; Huang, R.-Q. Tetrahedron Lett. 2007, 48, 1221-1224. doi:10.1016/j.tetlet.2006.12.047

29. Konodo, S.-I.; Hiraoka, Y.; Kurumatani, N.; Yano, Y. Chem. Commun. 2005, 1720-1722. doi:10.1039/b417304j

30. Ihm, H.; Yun, S.; Kim, H. G.; Kim, J. K.; Kim, K. S. Org. Lett. 2002, 4, 2897-2900. doi:10.1021/ol026373h

31. Choi, K.; Hamilton, A. D. Angew. Chem., Int. Ed. 2001, 40, 3912-3915. doi:10.1002/1521-3773(20011015)40:20<3912::AID-ANIE3912>3.0.CO ;2-R

32. Kwon, T. H.; Jeong, K.-S. Tetrahedron Lett. 2006, 47, 8539-8541. doi:10.1016/j.tetlet.2006.09.105

33. Xu, Z.; Kim, S.; Lee, K.-H.; Yoon, J. Tetrahedron Lett. 2007, 48, 3797-3800. doi:10.1016/j.tetlet.2007.03.159

34. PC Mode; Serena Software, 1993.

Energy minimization: MMX using standard constants and dielectric constant of 1.5 .

35. Gale, P. A.; Hiscock, J. R.; Moore, S. J.; Caltagirone, C.; Hursthouse, M. B.; Light, M. E. Chem.-Asian J. 2009, 5, 555-561. doi:10.1002/asia.200900230

36. Lowe, A. J.; Dyson, G. A.; Pfeffer, F. M. Org. Biomol. Chem. 2007, 5, 1343-1346. doi:10.1039/b703626b

37. Job, P. Ann. Chim. Appl. 1928, 9, 113-203.

38. Bissel, R. A.; de Silva, A. P.; Gunaratne, H. Q. N.; Lynch, P. L. M.; Maguire, G. E. M.; Sandanayake, K. R. A. S. Chem. Soc. Rev. 1992, 21, 187-195. doi:10.1039/cs9922100187

39. Chou, P.-T.; Wu, G.-R.; Wei, C.-Y.; Cheng, C.-C.; Chang, C.-P.; Hung, F.-T. J. Phys. Chem. B 2000, 104, 7818-7829. doi:10.1021/jp001001g

40. Haldimann, M.; Zimmerli, B.; Als, C.; Gerber, H. Clin. Chem. 1998, 44, 817-824.

And references therein.

41. Kim, H.; Kang, J. Tetrahedron Lett. 2005, 46, 5443-5445. doi:10.1016/j.tetlet.2005.06.068

42. Singh, N.; Jang, D. O. Org. Lett. 2007, 9, 1991-1994. doi:10.1021/ol070592r And references cited therein.

43. Singh, N.; Jung, H. J.; Jang, D. O. Tetrahedron Lett. 2009, 50, 71-74. doi:10.1016/j.tetlet.2008.10.088

44. Ghosh, K.; Sen, T. Tetrahedron Lett. 2008, 49, 7204-7208. doi:10.1016/j.tetlet.2008.10.009

45. Ghosh, K.; Saha, I. Supramol. Chem. 2010, 22, 311-317. doi:10.1080/10610270903469773

46. Singh, N. J.; Jun, E. J.; Chellappan, K.; Thangadurai, D.; Chandran, R. P.; Hwang, I.-C.; Yoon, J.; Kim, K. S. Org. Lett. 2007, 9, 485-488. doi:10.1021/ol062849b

47. Shiraishi, Y.; Kohno, Y.; Hirai, T. J. Phys. Chem. B 2005, 109 , 19139-19147. doi:10.1021/jp052645x

48. Inoue, H.; Hida, M.; Nakashima, N.; Yoshihara, K. J. Phys. Chem. 1982, 86, 3184-3188. doi:10.1021/j100213a024

49. Ghosh, K.; Saha, I. Tetrahedron Lett. 2008, 49, 4591-4595. doi:10.1016/j.tetlet.2008.05.096 


\section{License and Terms}

This is an Open Access article under the terms of the Creative Commons Attribution License

(http://creativecommons.org/licenses/by/2.0), which permits unrestricted use, distribution, and reproduction in any medium, provided the original work is properly cited.

The license is subject to the Beilstein Journal of Organic Chemistry terms and conditions:

(http://www.beilstein-journals.org/bjoc)

The definitive version of this article is the electronic one which can be found at:

doi:10.3762/bjoc. 7.34 